\title{
Investing in water supply resilience considering uncertainty and management flexibility
}

Bryan T. Adey PhD

Professor, Institute of Construction and Infrastructure Management, ETH, Zurich, Switzerland (Orcid:0000-0002-4932-5901)

\section{Claudio Martani PhD}

Assistant Professor, School of Construction Management Technology,

Purdue University, IN, USA (Orcid:0000-0002-9039-0908) (corresponding author: cmartani@purdue.edu)

\author{
Jürgen Hackl PhD \\ Professor, School of Engineering, University of Liverpool, Liverpool, UK \\ (Orcid:0000-0002-8849-5751)
}

This paper demonstrates how to make investment decisions that optimally improve water supply resilience, taking into consideration both future uncertainty and management flexibility. The demonstration is done by evaluating investment strategies for a $38 \mathrm{Ml} / \mathrm{d}$ water treatment plant serving an urban area with approximately 75000 inhabitants, where there is uncertainty with respect to future population growth, industrial production, external demand and the amount of rainfall due to climate change. It is shown that the quantification and comparison of the possible reductions in service and intervention costs over comparably long periods enables the optimal investment decisions - that is, the ones with the optimal trade-offs between stakeholders. Additionally, it can be seen that the used methodology enables the consistent and transparent consideration of (a) the concerns of multiple stakeholders, (b) the future deep uncertainty associated with key concerns and (c) the flexibility of infrastructure managers to make decisions in the future using new information. The methodology also ensures that managers have clear plans of action and considerable insight into the extent of required future financing.

Keywords: climate change/infrastructure planning/municipal \& public service engineering/natural resources/risk \& probability analysis/water supply

\section{Notation}

$C_{\text {econ_int }}$ economic costs per intervention

$C_{\text {ecos }} \quad$ unit cost for the lack of water in the reservoir for the ecosystem

$C_{\mathrm{ecoS}}$

$C_{\text {env }}$

$C_{\text {env_int }}$

$C_{\text {ext }}$

$C_{\text {hos }}$

$C_{\text {ind }}$

$C_{\text {int }}$

$C_{\text {priv }}$

$C_{\text {sch }}$

$C_{\text {wr }}$

$C_{\text {wr_hos }}$

$C_{\text {wr_ind }}$

$C_{\text {wr_priv }}$

$C_{\text {wr_sch }}$

$C_{1 \text { fish }}$

$D_{\text {ext }}$

$D_{\text {hos }}$

$D_{\text {ind }}$

$D_{\text {priv }}$
$D_{\text {sch }}$

$D_{\mathrm{x}} \quad$ demand per stakeholder group

$L_{\text {min_f }} \quad$ minimal acceptable level of water in the reservoirs

for fish to pass

$L_{\text {min_s }} \quad$ minimal acceptable level of water in the reservoir for water supply

$L_{\text {real }} \quad$ actual level of water in the reservoir

$N_{\text {priv }} \quad$ number of people using water for private consumption

$P_{\text {ind }} \quad$ industry production

$W_{\text {priv }} \quad$ precipitation

$P_{\mathrm{s}} \quad$ probability of external demand

$S_{\mathrm{t}} \quad$ supply

$S_{\mathrm{x}} \quad$ share of population in stakeholder group

$\delta$ a binary variable describing the level of water in the reservoirs that allows fish to pass

$\lambda$ a binary variable describing the level of water in the reservoirs that negatively affects the ecological system

\section{Introduction}

The provision of high-quality drinking water to urban areas is essential. Doing so continuously over long periods efficiently and effectively, however, is a challenging task. Part of the challenge is that decisions are made now as to how substantial amounts of money is spent to construct infrastructure that will service urban areas for decades when the exact service required in that period is 
Smart Infrastructure and Construction

Volume 175 Issue 3
Investing in water supply resilience

considering uncertainty and management

flexibility

Adey, Martani and Hackl uncertain. Four reasons for this uncertainty are the uncertain growth in the population of urban areas, the uncertain water needs of industry, the uncertain needs of neighbouring communities and the uncertain effects of climate change on rainfall patterns.

In this paper, it is shown how to make investment decisions that optimally improve water supply resilience where there is uncertainty with respect to future population growth, the water requirements of industry and neighbouring communities and the amount of rainfall due to climate change. It is shown that the quantification and comparison of the possible reductions in service and intervention costs over comparably long periods enables the optimal investment decisions - that is, ones with the optimal trade-offs between stakeholders. Additionally, it can be seen that the used methodology enables the consistent and transparent consideration of $(a)$ the concerns of multiple stakeholders, $(b)$ the future deep situational uncertainties and $(c)$ the flexibility of infrastructure managers to make decisions in the future using new information.

The methodology, which builds on recent work by de Neufville et al. (2019) and Esders et al. (2020), is the first attempt to systematically support decision makers in optimally improving water supply resilience taking into consideration both future uncertainty and management flexibility, and it involves (a) establishing an objective function that covers the (economic, social and environmental) interests of all stakeholders, (b) modelling the uncertainty of the variables that have a significant influence on the costs and benefits of the possible investments and $(c)$ evaluating the possible management strategies, which are comprised of initial and subsequent investments. The example infrastructure investigated is a $38 \mathrm{Ml} / \mathrm{d}$ water treatment plant serving an urban area with around 75000 inhabitants, where there is uncertainty with respect to amount of rainfall due to climate change and future population growth. It is found that the optimal investment decision to improve water supply resilience is to do nothing now and wait for new information.

\section{Background}

The potential benefit of making investment decisions on infrastructure, taking into consideration both the future uncertainty and management flexibility, has received increasing attention in recent years. Some of the most relevant example works in the field are shown in Table 1, along with the future uncertainty and impacts considered in each investigation, as well as the simulation method used.

It can be noticed from Table 1 that in all the research listed, the economic impacts related to the interventions themselves has been considered exclusively - that is, excluding the monetary and nonmonetary effects on other stakeholders. Additionally, none of the research has focused on water treatment infrastructure. With reference to the simulation method, in the majority of examples, researchers have used the Monte Carlo method to simulate the variable behaviour (11/15) over time, due to its suitability for simulating scenarios, considering multiple uncertain factors. Since multiple variables are considered in the example used in this paper - that is, the population dynamics, the water needs of industry and neighbouring communities and amount of rain, the Monte Carlo Method was used.

\section{Converting resilience to climate change and population growth into an objective function}

Improving water supply resilience means reducing the losses in service that stakeholders might experience over time (Adey et al., 2020). The objective function to evaluate investment strategies must represent the wishes of all stakeholders. The optimal investment strategy is the one that provides the best trade-off between resilience enhancement -that is, the reductions in potential losses of service and additional interventions. When reduction in service loss are quantified in monetary units (as suggested by Adey et al., 2019a), the optimal investment strategy itself minimises the expected service losses and intervention costs over the investigated period. The optimal investment option is the part of the investment strategy that currently requires the commitment of resources. The example objective function is

1. $\operatorname{Min} Z=\sum_{t=1}^{T}\left(C_{\mathrm{int}}+C_{\mathrm{wr}}+C_{\mathrm{env}}\right)$

where, $C_{\mathrm{int}}=$ intervention costs; $C_{\mathrm{wr}}=$ inadequate water supply costs; $C_{\text {env }}=$ environmental costs;

2. $C_{\text {int }}=C_{\text {econ int }}+C_{\text {env int }}$

$C_{\text {econ int }}=$ economic costs per intervention; $C_{\text {env } \mathrm{i}}=$ environmental costs per intervention;

3. $C_{\mathrm{wr}}=C_{\mathrm{hos}}+C_{\mathrm{ind}}+C_{\mathrm{sch}}+C_{\mathrm{priv}}+C_{\mathrm{ext}}$

where the values are estimated considering that the water would first be cut off to any parties outside the serviced area, $C_{\text {ext }}$, then within the serviced area - to the private residences, $C_{\text {priv }}$, then the schools, $C_{\text {sch }}$, then the industry, $C_{\text {ind }}$, and then the hospital, $C_{\text {hos }}$. The variables used to estimate water supply and demand are shown in Table 2.

where $N_{\text {priv }}=$ number of people using water for private consumption; $P_{\text {ind }}=$ industry production; $W_{\text {rain }}=$ precipitation; $P_{\mathrm{s}}=$ probability of external demand; $D_{x}=$ demand per stakeholder group, $S_{x}=$ share of population in stakeholder group

4. $C_{\text {env }}=\delta \cdot C_{\text {fish }}+\left(\lambda \times\left(L_{\text {min_s }}-L_{\text {real }}\right) \times C_{\text {ecoS }}\right)$

where, $\delta$ is a binary variable describing the level of water in the reservoirs that allows fish to pass, given by 
Table 1. Examples of research on appraising investments considering future uncertainty and management flexibility

\begin{tabular}{|c|c|c|c|c|}
\hline Infrastructure & Source & Future uncertainty modelled & Impacts considered & $\begin{array}{l}\text { Simulation } \\
\text { method } \\
\text { used }\end{array}$ \\
\hline \multirow[t]{2}{*}{ Hospitals and clinics } & $\begin{array}{l}\text { (de Neufville et al., } \\
\text { 2008) }\end{array}$ & $\begin{array}{l}\text { Changes in demographics, changes in patterns, } \\
\text { causes and effects of health and disease, } \\
\text { changes in medical technology }\end{array}$ & $\begin{array}{l}\text { Economic cost of } \\
\text { intervention and net } \\
\text { benefit for operation }\end{array}$ & $\begin{array}{r}\text { Monte } \\
\text { Carlo }\end{array}$ \\
\hline & (Esders et al., 2020) & Number of patients & $\begin{array}{l}\text { Economic cost of } \\
\text { intervention and net } \\
\text { benefit for operation }\end{array}$ & $\begin{array}{l}\text { Binomial } \\
\text { trees }\end{array}$ \\
\hline \multirow{2}{*}{$\begin{array}{l}\text { Engineering systems for on- } \\
\text { shore liquefied natural } \\
\text { gas and petrol plants }\end{array}$} & (Cardin et al., 2015) & Demand of liquefied natural gas & $\begin{array}{l}\text { Economic cost of } \\
\text { intervention }\end{array}$ & $\begin{array}{l}\text { Monte } \\
\text { Carlo }\end{array}$ \\
\hline & $\begin{array}{l}\text { (Santa-Cruz and } \\
\text { Heredia-Zavoni, } \\
\text { 2011) }\end{array}$ & $\begin{array}{l}\text { Economic variables (hydrocarbon prices and } \\
\text { maintenance costs) and the engineering } \\
\text { variables (the probability of fatigue damage) }\end{array}$ & $\begin{array}{l}\text { Economic cost of } \\
\text { intervention }\end{array}$ & $\begin{array}{r}\text { Monte } \\
\text { Carlo }\end{array}$ \\
\hline $\begin{array}{l}\text { Engineering systems for } \\
\text { waste and energy }\end{array}$ & (Cardin and $\mathrm{Hu}, 2016$ ) & $\begin{array}{l}\text { Required capacity of waste disposal and energy } \\
\text { supply }\end{array}$ & $\begin{array}{l}\text { Economic cost of } \\
\text { intervention and net } \\
\text { benefit for operation }\end{array}$ & $\begin{array}{r}\text { Monte } \\
\text { Carlo }\end{array}$ \\
\hline Bridges & $\begin{array}{l}\text { (Ellingham and } \\
\text { Fawcett, 2007) }\end{array}$ & $\begin{array}{l}\text { Weight and spacing of the axles related to traffic } \\
\text { demand }\end{array}$ & $\begin{array}{l}\text { Economic cost of } \\
\text { intervention and net } \\
\text { benefit for operation }\end{array}$ & $\begin{array}{l}\text { Monte } \\
\text { Carlo }\end{array}$ \\
\hline Highways & (Fawcett et al., 2014) & Traffic demand & $\begin{array}{l}\text { Economic cost of } \\
\text { intervention and net } \\
\text { benefit for operation }\end{array}$ & $\begin{array}{r}\text { Monte } \\
\text { Carlo }\end{array}$ \\
\hline \multirow[t]{2}{*}{ Parking silos } & $\begin{array}{l}\text { (De Neufville and } \\
\text { Scholtes, 2011; De } \\
\text { Neufville et al., } \\
\text { 2006) }\end{array}$ & Number of parking plots required & $\begin{array}{l}\text { Economic cost of } \\
\text { intervention and net } \\
\text { benefit from rent }\end{array}$ & $\begin{array}{r}\text { Monte } \\
\text { Carlo }\end{array}$ \\
\hline & (Elvarsson et al., 2021) & $\begin{array}{l}\text { Number of parking plots required due to the } \\
\text { outbreak of autonomous vehicles }\end{array}$ & $\begin{array}{l}\text { Economic cost of } \\
\text { intervention and } \\
\text { benefit from rent }\end{array}$ & $\begin{array}{r}\text { Monte } \\
\text { Carlo }\end{array}$ \\
\hline Office buildings' façades & (Esders et al., 2016) & Operating costs & $\begin{array}{l}\text { Economic cost of } \\
\text { intervention and net } \\
\text { benefit from } \\
\text { operation }\end{array}$ & $\begin{array}{l}\text { Binomial } \\
\text { trees }\end{array}$ \\
\hline $\begin{array}{l}\text { Space sharing in general } \\
\text { buildings space }\end{array}$ & $\begin{array}{l}\text { (Fawcett and } \\
\text { Chadwick, 2007; } \\
\text { Fawcett and Rigby, } \\
\text { 2009) }\end{array}$ & Demand of working space & $\begin{array}{l}\text { Economic cost of } \\
\text { intervention and net } \\
\text { benefit from } \\
\text { operation }\end{array}$ & $\begin{array}{l}\text { Agent- } \\
\text { based } \\
\text { simulation } \\
\text { model }\end{array}$ \\
\hline $\begin{array}{l}\text { Layout of buildings' ground } \\
\text { floor }\end{array}$ & $\begin{array}{l}\text { (Ellingham and } \\
\text { Fawcett, 2007) }\end{array}$ & Commercial rents & $\begin{array}{l}\text { Economic cost of } \\
\text { intervention and } \\
\text { benefit from rent }\end{array}$ & $\begin{array}{l}\text { Binomial } \\
\text { trees }\end{array}$ \\
\hline $\begin{array}{l}\text { Vertical expansion of office } \\
\text { buildings }\end{array}$ & $\begin{array}{l}\text { (Guma and de } \\
\text { Neufville, 2008) }\end{array}$ & $\begin{array}{l}\text { Future cash flows (rents) and demand for office } \\
\text { space }\end{array}$ & $\begin{array}{l}\text { Economic cost of } \\
\text { intervention and } \\
\text { operation }\end{array}$ & $\begin{array}{l}\text { Monte } \\
\text { Carlo }\end{array}$ \\
\hline $\begin{array}{l}\text { Ground floor ceilings in } \\
\text { general buildings }\end{array}$ & (Martani et al., 2018) & Use change rate & $\begin{array}{l}\text { Economic cost of } \\
\text { intervention and net } \\
\text { benefit from } \\
\text { operation }\end{array}$ & $\begin{array}{r}\text { Monte } \\
\text { Carlo }\end{array}$ \\
\hline $\begin{array}{l}\text { Energy retrofit in existing } \\
\text { buildings }\end{array}$ & (Ashuri et al., 2011) & Energy price & $\begin{array}{l}\text { Economic cost of } \\
\text { intervention and net } \\
\text { benefit from } \\
\text { operation }\end{array}$ & $\begin{array}{l}\text { Monte } \\
\text { Carlo }\end{array}$ \\
\hline
\end{tabular}

Table 2. Variables with significant influence on investment

$\begin{array}{lcc}\text { Variables } & \text { Symbol } & \text { Estimate } \\ \text { Supply } & S_{t} & S_{t-1}-S A_{t-1}+W_{\text {rain }} \\ \text { Private demand } & D_{\text {priv }} & N_{\text {priv }} \times W_{\text {priv }} \\ \text { Industry demand } & D_{\text {ind }} & P_{\text {ind }} \times W_{\text {ind }} \\ \text { School demand } & D_{\text {sch }} & N_{\text {private }} \times S_{\text {sch }} \times W_{\text {sch }} \\ \text { Hospital demand } & D_{\text {hos }} & N_{\text {private }} \times S_{\text {hos }} \times W_{\text {hos }} \\ \text { External demand } & D_{\text {ext }} & Z \times\left(P_{S} \times Q_{S} \times C_{\text {wr_average }}\right)\end{array}$


Smart Infrastructure and Construction

Volume 175 Issue 3
Investing in water supply resilience

considering uncertainty and management

flexibility

Adey, Martani and Hackl
5. $\left(L_{\text {real }}<L_{\text {min_f }}\right)=1 ;\left(L_{\text {real }}<L_{\text {min } \_f}\right)=0$

6. $\quad C_{\text {fish }}=N_{\text {fish }} \times C_{\text {fish }}$

and $\lambda$ is a binary variable describing the level of water in the reservoirs that negatively affects the ecological system, given by

7. $\left(L_{\text {real }}<L_{\text {min__s }}\right)=1 ;\left(L_{\text {real }} \geq L_{\text {min_s }_{-}}\right)=0$

$L_{\text {min } \mathrm{f}}=$ minimal acceptable level of water in the reservoirs for fish to pass; $L_{\min \_\mathrm{s}}=$ minimum acceptable level of water in the reservoir for water supply; $L_{\text {real }}=$ actual level of water in the reservoir, which depends on the level of water in the reservoir at time $t-1$, and both the demand of water supply and the amount of precipitation in the time period between $t-1$ and $t ; C_{\mathrm{ecoS}}=$ value of lack of water in the reservoir for the ecosystem per $\mathrm{Ml} ; C_{1}$ fish $=$ value of blocking one fish.

The monetised values of reductions in service per unit are given in Table 3 (as done for transport infrastructure in Adey et al., 2019b; Papathanasiou et al., 2019).

\section{Uncertainty}

To consistently and transparently consider trade-offs between resilience to climate change, population growth, the needs of industry and neighbouring communities and intervention costs, the uncertainty with respect to not being able to provide sufficient water has to be modelled. Although it is not possible to model this uncertainty perfectly, it is possible to model the uncertainties related to a number of key variables - that is, the ones that are expected to have the largest effect on the optimality of the possible strategies. For the example, these are (i) the population size, which affects the amount of water consumed in private residences and hospitals, (ii) precipitation, which affects the amount of water that can be supplied, (iii) the amount of water required by industry, which is linked to the economy and (iv) the amount of water required by externals. The uncertainty on these variables were modelled because possible future changes in these variables were deemed both non-unlikely and particularly impactful on the objective function. Other sources of uncertainty - such as the daily water consumption per person - may be an added concern in future studies. The information used to develop the models is given in Table 5. The results are shown in Figure 1 and Figure 2.

Table 3. Unit values to estimate service reduction costs

$\begin{array}{lccc}\text { Symbol } & \text { Value } & \text { Symbol } & \text { Value } \\ C_{\text {wr_priv }} & 2 \mathrm{f} / \mathrm{per} \text {./day } & C_{\text {wr_sch }} & 500 \mathrm{f} / \mathrm{sch} . / \mathrm{day} \\ C_{\text {wr_ind }} & 3000 \mathrm{f} / \text { ind./day } & C_{1} \text { fish } & 20 \mathrm{f} / \mathrm{fish} / \mathrm{year} \\ C_{\text {wr_hos }} & 10000 \mathrm{f} / \mathrm{hos} . / \text { day } & C_{\text {ecos }} & 60 \mathrm{f} / \mathrm{Ml} / \mathrm{year}\end{array}$

Table 4. Information used to develop uncertainty models

\begin{tabular}{|c|c|}
\hline Uncertainty & Information \\
\hline Population size & $\begin{array}{l}\text { The uncertainty associated with population size } \\
\text { is modelled by projecting the evolution over } \\
\text { the last } 30 \text { years (i.e. 1991-2021) into the } \\
\text { future as the mean, and increasing the } \\
\text { standard deviation over time. The projection } \\
\text { provides the mean expected trajectory, around } \\
\text { which an increasing standard deviation is set to } \\
\text { reflect the possible unexpected future changes. }\end{array}$ \\
\hline Precipitation & $\begin{array}{l}\text { The uncertainty associated with the evolution of } \\
\text { population is modelled from the pattern of the } \\
\text { last } 110 \text { years (i.e. 1911-2021). The pattern is } \\
\text { used to set the future trend, considering a } \\
\text { slightly decreasing mean tendency. This was } \\
\text { done accounting for the potential } \\
\text { consequence of climate changes in the future. } \\
\text { Around the mean, a large standard deviation is } \\
\text { set to reflect the amplitude of yearly variation } \\
\text { registered in the past. }\end{array}$ \\
\hline $\begin{array}{l}\text { Water required } \\
\text { from industry }\end{array}$ & $\begin{array}{l}\text { The industry is expected to increase in } \\
\text { production, though possible unexpected } \\
\text { future changes are non-negligible in the } \\
\text { long term. This result in a model of the } \\
\text { water required from industry that considers } \\
\text { an increasing mean value and an increasing } \\
\text { standard deviation. }\end{array}$ \\
\hline $\begin{array}{l}\text { External demand } \\
\text { for water }\end{array}$ & $\begin{array}{l}\text { The likelihood that adjacent communities will } \\
\text { have future water shortages, was modelled as } \\
\text { a Poisson distribution with a constant mean } \\
\text { rate of occurrence, independent from the } \\
\text { previous events. }\end{array}$ \\
\hline
\end{tabular}

Table 5. Investment strategies to ensure water supply resilience

\begin{tabular}{|c|c|c|c|}
\hline Label & Description & When & Time required \\
\hline 0 & 0 & 0 & 0 \\
\hline $1 a$ & $\mathrm{RL} 2 \mathrm{Ml} / \mathrm{d}$ & 0 & 2 \\
\hline $1 b$ & $\mathrm{RL} 2.5 \mathrm{Ml} / \mathrm{d}$ & 0 & 2 \\
\hline $1 c$ & $\mathrm{RL} 6 \mathrm{Ml} / \mathrm{d}$ & 0 & 2 \\
\hline $1 d$ & $\mathrm{RL} 7 \mathrm{Ml} / \mathrm{d}$ & 0 & 2 \\
\hline $2 a$ & RWA $20 \mathrm{ML} / \mathrm{d}$ & 0 & 2 \\
\hline $2 b$ & RWA $40 \mathrm{ML} / \mathrm{d}$ & 0 & 2 \\
\hline $2 c$ & RWA $20 \mathrm{ML} / \mathrm{d}$ & 30 & 2 \\
\hline $2 d$ & RWA $40 \mathrm{ML} / \mathrm{d}$ & 50 & 2 \\
\hline $2 \mathrm{e}$ & RWA 40; $20 \mathrm{ML} / \mathrm{d}$ & $0 ; 10$ & $2 ; 2$ \\
\hline $2 f$ & RWA 40; $1010 \mathrm{ML} / \mathrm{d}$ & $10 ; 15 ; 30$ & $2 ; 1 ; 1$ \\
\hline 3 & RWA $35 \mathrm{ML} / \mathrm{d}$ & 45 & 5 \\
\hline Dynamic & & Variable & \\
\hline
\end{tabular}

$\mathrm{RL}$, reduce leakage; RWA, raise water availability

\section{Strategies for resilience and their optimality}

Once the future uncertainty with the key parameters is estimated, managers have to identify the different possible ways to ensure that they can continue to provide service, taking into consideration the many possible futures of what might happen. This step is a precursor to determining which of these interventions should be executed and in which order they can ensure the optimal level of resilience. For the example, the possible interventions are to reduce 


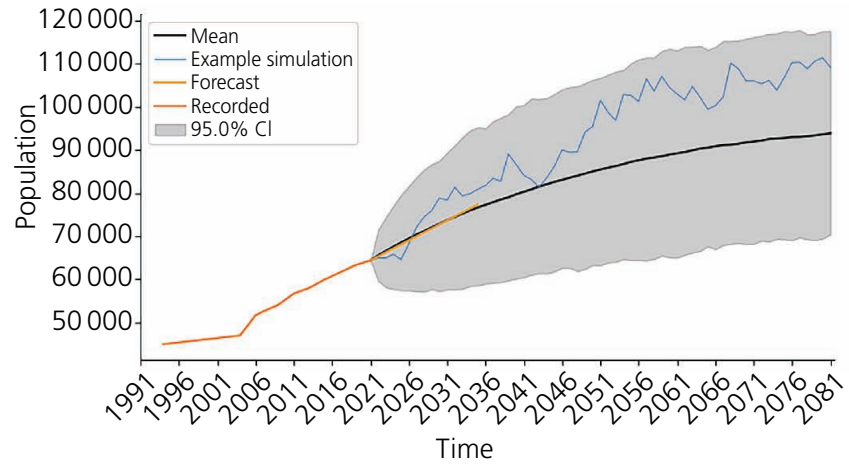

(a)

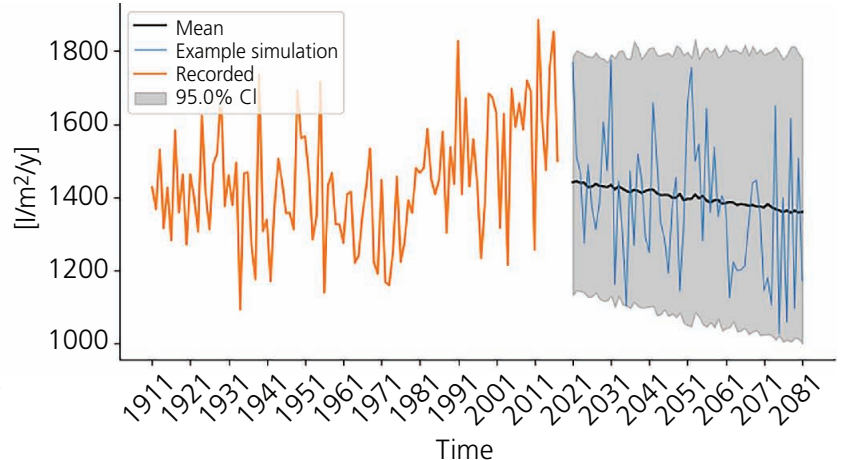

(b)

Figure 1. Example models of (a) population and (b) precipitation uncertainties. $\mathrm{Cl}$, confidence interval

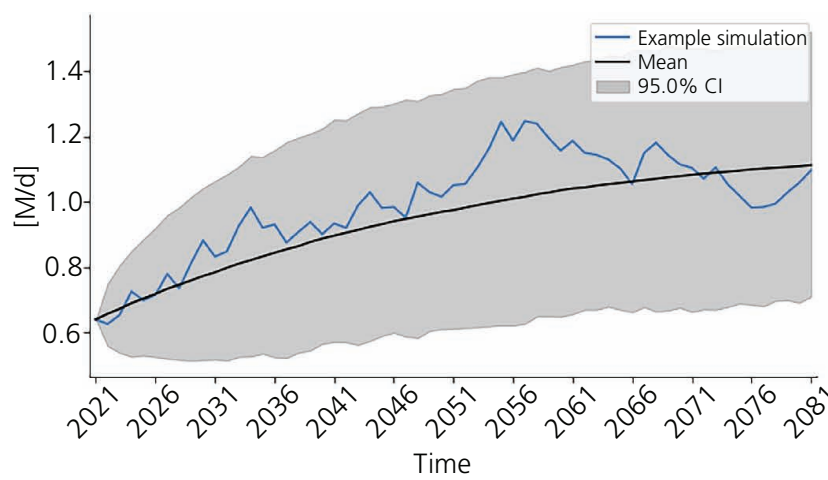

(a)

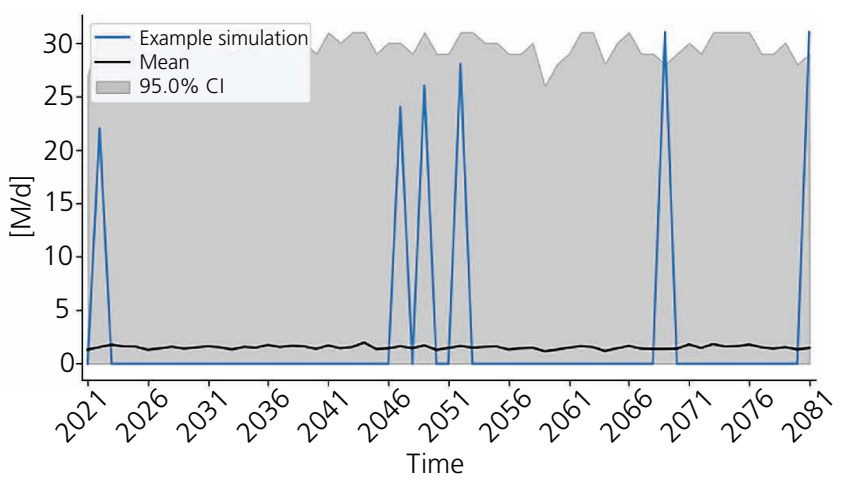

(b)

Figure 2. Example models of (a) industry demand and (b) external demand uncertainties

leakage by different amounts and to increase water supply by varying amounts. These are then combined into either static strategies - that is, it is decided now what is to be done over the investigated period, or dynamic strategies - that is, it is decided only what is to be presently done, and then, it is agreed that the situation will be reanalysed in the future using the same objective function. Once established, these strategies are analysed by running simulations of what may happen in the future. In the example, many different possible strategies were identified together with their total costs, in terms of reductions in service and interventions costs, using 1000 Monte Carlo simulations. A sample of the strategies used in the examples, the estimations of the costs and net benefit when compared to the reference strategy 0 , and the cumulative distributions of the total costs are given in Tables 5 and 6 and Figure 3. Figure 4 shows the probabilities of executing interventions $2 \mathrm{a}$ and 3 in the investigated period when the dynamic strategy is followed. The probabilities of all other interventions are 0 .

With respect to the static strategies, it can be seen that

- Strategy $2 \mathrm{f}$ - that is, to raise the water availability by $40 \mathrm{ML} / \mathrm{d}$ at year 10 , and then by $10 \mathrm{ML} / \mathrm{d}$ at year 15 and then again at 30 , is the optimal strategy - that is, to yield the lowest average total costs/effects on service $(132 \mathrm{mf})$. It has also a relatively high benefit-cost ratio. The selection of $2 \mathrm{f}$ would mean no investment now but investments are yet to come in year 15 and 30 .

- Strategy 3 and 2b, also have high net benefit, but lower benefit-cost ratios than $2 \mathrm{f}$. The selection of strategy 3 or strategy $2 \mathrm{~b}$ would mean investing 88 or $62 \mathrm{~m}$ over 60 years $£$. As not all of this money does not need to be committed now, it means our investment option would be to raise water availability by $20 \mathrm{ML} / \mathrm{d}$ in the next 5 years.

- Strategy $1 \mathrm{c}-$ that is, to reduce leakage by $2 \mathrm{Ml} / \mathrm{d}$ immediately, will result in significantly higher total costs (429 $\mathrm{mf})$ than in strategy $2 \mathrm{f}(297 \mathrm{mf})$.

- The least uncertainty is associated with strategy 3 , and the largest uncertainty is with strategy 0 .

- Strategy 0 could incur the lowest but could also incur the highest costs.

It can also be seen, however, that the dynamic strategy provides the lowest average total costs, $70 \mathrm{~m} £$ (in terms of the overall sum between the intervention costs and monetarised reduction in service) - that is, it provides the optimal balance between resilience enhancement and intervention costs. It is also more certain than 0 but less than 3 . 
Smart Infrastructure and Construction

Volume 175 Issue 3
Investing in water supply resilience

considering uncertainty and management

flexibility

Adey, Martani and Hackl

Table 6. Net benefit of strategies

\begin{tabular}{|c|c|c|c|c|c|c|c|c|}
\hline \multirow{3}{*}{ Label } & \multicolumn{8}{|c|}{ Results [mf] } \\
\hline & {$[\mathrm{A}]$} & {$[\mathrm{B}]$} & {$[\mathrm{C}]$} & [D] & {$[E]$} & {$[F]$} & {$[\mathrm{G}]$} & {$[\mathrm{H}]$} \\
\hline & $\begin{array}{l}\text { Base NPC over } \\
60 \text { years (mid) }\end{array}$ & $\begin{array}{l}\text { Intervention costs } \\
\text { over } 60 \text { years }\end{array}$ & $\begin{array}{l}\text { NPC over } 60 \text { years } \\
\text { (mid) }[\mathrm{A}]+[\mathrm{B}]\end{array}$ & $\begin{array}{l}\text { Service } \\
\text { risk }\end{array}$ & $\begin{array}{c}\text { Total cost } \\
{[\mathrm{C}]+[\mathrm{D}]}\end{array}$ & $\begin{array}{c}\text { Benefit [D] of MS_0 } \\
-[D] \text { of MS_x }\end{array}$ & $\begin{array}{c}\mathrm{B} / \mathrm{C} \\
{[\mathrm{E}] /[\mathrm{C}]}\end{array}$ & $\begin{array}{l}\text { Net benefit } \\
{[E]-[C]}\end{array}$ \\
\hline 0 & 42 & 0 & 42 & 1368 & 1410 & 0 & - & - \\
\hline $1 a$ & 42 & 2 & $44^{a}$ & 923 & 967 & 444 & 10.2 & 401 \\
\hline $1 b$ & 42 & 3 & 45 & 780 & 824 & 588 & 13.2 & 543 \\
\hline $1 c$ & 42 & 28 & 70 & 359 & 429 & 1008 & 14.5 & 939 \\
\hline $1 d$ & 42 & 31 & 73 & 264 & 337 & 1104 & 15.1 & 1031 \\
\hline $2 a$ & 42 & 54 & 96 & 78 & 174 & 1290 & 13.4 & 1193 \\
\hline $2 b$ & 42 & 62 & 104 & 32 & 136 & 1335 & 12.9 & 1232 \\
\hline $2 c$ & 42 & 73 & 115 & 31 & 146 & 1337 & 11.6 & 1222 \\
\hline $2 d$ & 42 & 65 & 107 & 30 & 137 & 1337 & 12.5 & 1231 \\
\hline $2 e$ & 42 & 60 & 102 & 37 & 140 & 1330 & 13.0 & 1228 \\
\hline $2 f$ & 42 & 45 & 87 & 45 & 132 & 1323 & 15.3 & 1236 \\
\hline 3 & 42 & 88 & 130 & 3 & 133 & 1364 & 10.5 & 1234 \\
\hline dyn & 42 & 28 & 70 & 0.05 & 70 & 1368 & 19.4 & 1297 \\
\hline
\end{tabular}

${ }^{a}$ The best values of the static strategies are outlined in red in the table Bold values are the dynamic strategy (which are better than any static strategy) dyn, dynamic; NPC, net present cost

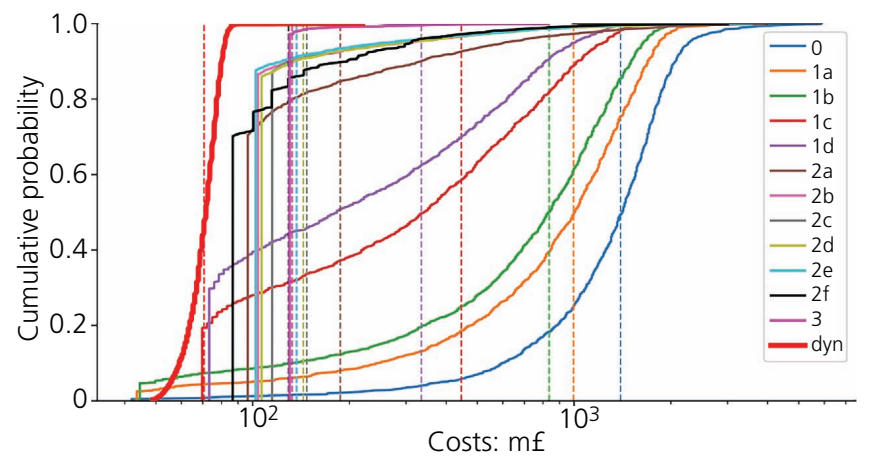

Figure 3. Expected total costs. dyn, dynamic

Here, it is also interesting to note the difference between using static and dynamic strategies in evaluating investment options. If static strategies are used in the example, no investment is currently required as $2 \mathrm{f}$, the optimal strategy only requires raising the water availability by $40 \mathrm{ML} / \mathrm{d}$ in year 10 (i.e. lowest cost, $132 \mathrm{mf}$, and highest net benefit, $1234 \mathrm{mf}$ ). This is predominantly due to the reduction in the costs of inadequate service as it reduces the probability of not being able to meet demand to almost 0 , and the costs of the staggered investments are discounted. If, however, another intervention strategy would be chosen (e.g. 2b), which is very close in total net benefit to $2 \mathrm{f}$, a large investment would be required now.

If a dynamic strategy is used in the example, it is clear that no investment is currently required, and that intervention $2 \mathrm{a}$ will happen relatively early over the investigated period and intervention 3 relatively late (Figure 4). Of course, these decisions will need to be made at some point of time in the future. Considering that most managers do not seriously commit themselves to financing for 60 years ahead of time, the use of dynamic strategies provides a more accurate picture of reality through the consideration of management flexibility and leads to improved investment decisions.

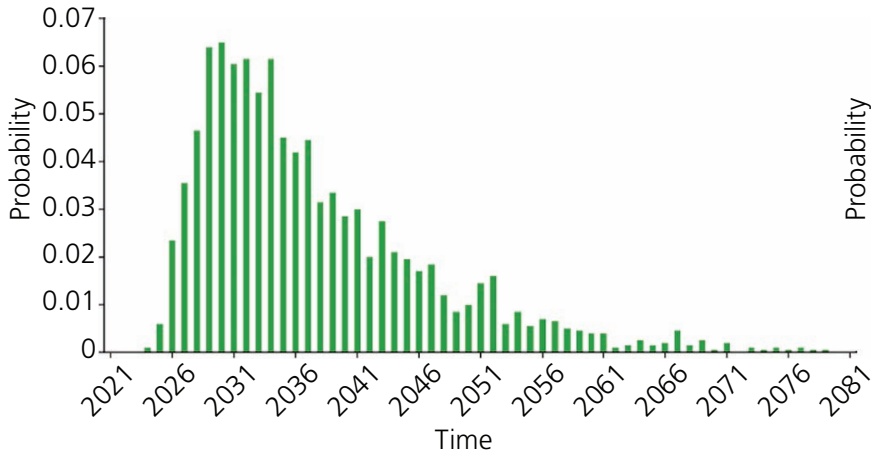

(a)

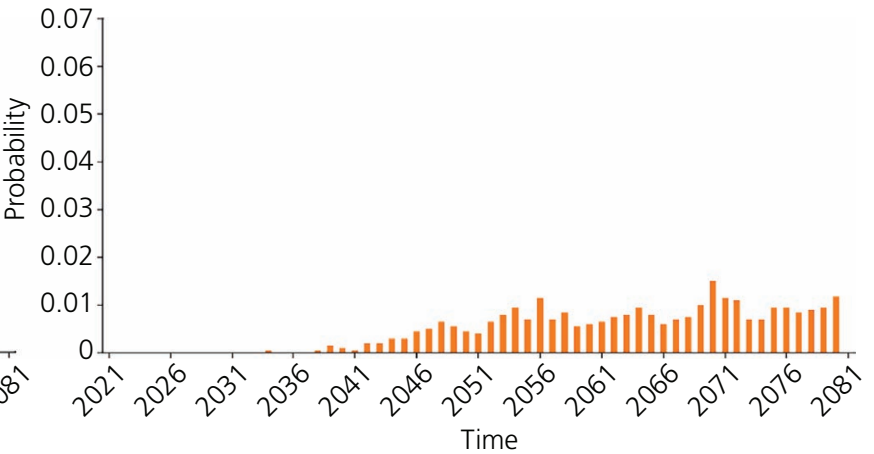

(b)

Figure 4. Probabilities of interventions (a) 2a and (b) 3 with the dynamic strategy 

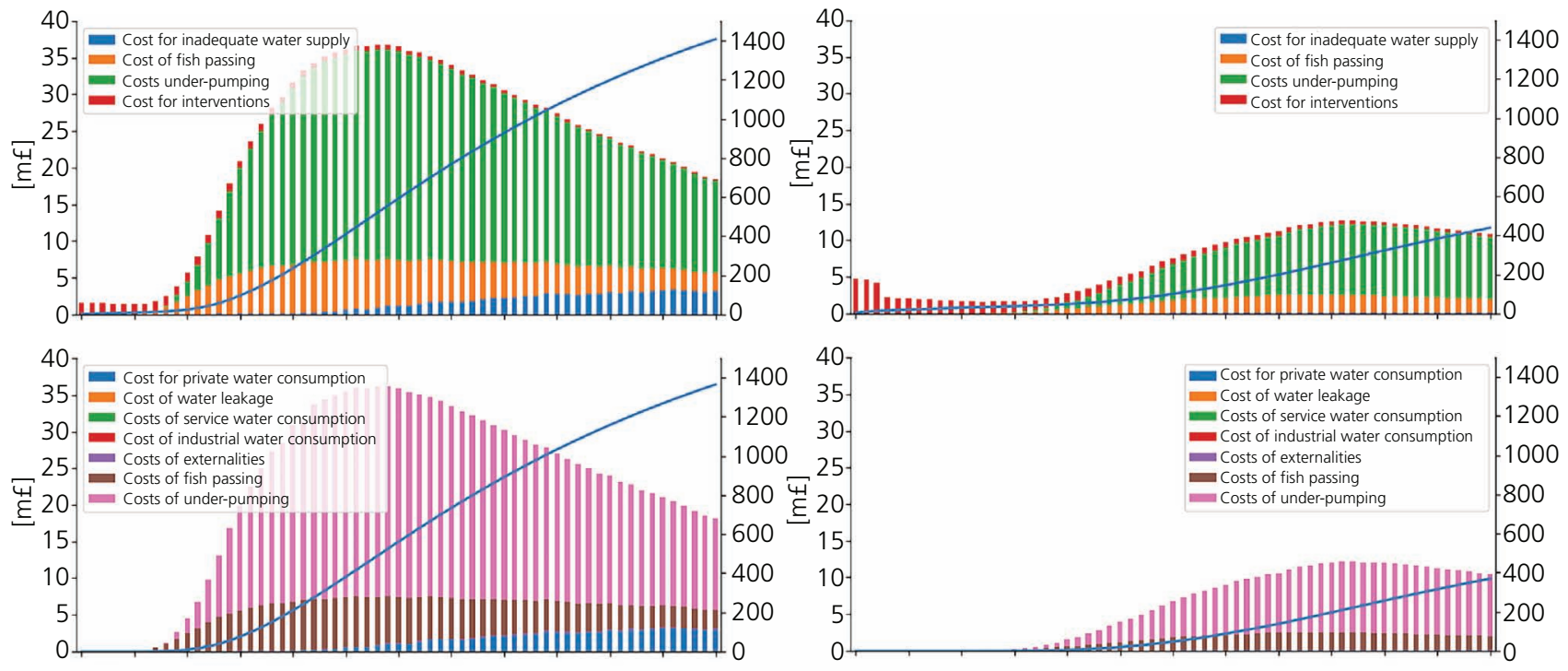

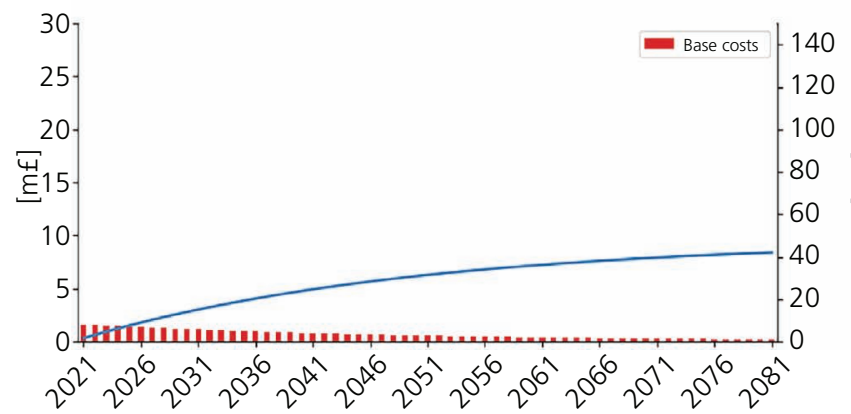

(a)

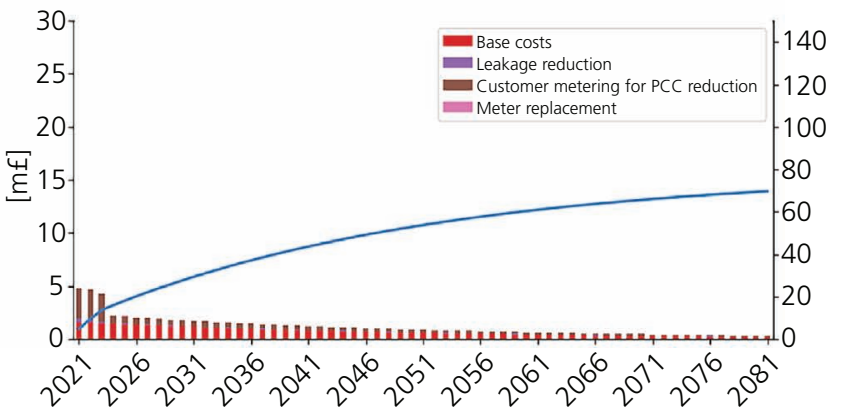

(b)

Figure 5. Costs associated with (a) strategy 0: total costs, costs of inadequate service and intervention costs and (b) strategy $1 \mathrm{c}$ : total costs, costs of inadequate service and intervention costs. PCC, per capital consumption

\section{Understanding cost drivers}

In an uncertain environment, aside from the estimation of expected costs, with or without sensitivity analyses, managers need to have an idea on what is likely to contribute to these costs and who will bear them and why. This type of information needs to be generated in every strategy. Examples for three static strategies and the dynamic strategy are shown in Figures 5 and 6. Additionally, the uncertainty associated with the costs can be shown. The probability density function (pdfs) and cumulative distribution function (cdfs) for the total costs of strategies $0,1 \mathrm{c}$ and $2 \mathrm{~b}$, and dynamic total costs are shown in Figures 7 and 8.

These graphs provide significant insight into the cost drivers and the stakeholders who must bear these costs, as well as why and when. For example, it can be seen for strategy 0 that a large percentage of the total costs $(1390 \mathrm{m£}$, with a confidence interval for the 1000 simulations that ranges between 129 and $3266 \mathrm{mf}$ ) are due to the high environmental cost of pumping water beyond the critical intake level, but that the cost of fish not passing and the cost of unmet demand contributes significantly. The intervention costs, which are only due to routine maintenance over time, are relatively small in comparison. It can, however, also be seen that both strategies $1 \mathrm{c}$ and $2 \mathrm{f}$ significantly reduce these environmental costs but have increased intervention costs, due to the cost of leakage reduction and the costs of reservoir expansion.

Figures 7 and 8 show the expected total costs - that is, the sum of the cost for inadequate service and the costs of intervention for over 60 years. Strategy 0 (Figures 7(a) and 7(b)) has mean expected total costs of $1390 \mathrm{mf}$, with a confidence interval that ranges between 129 and $3266 \mathrm{mf}$. Strategy 1c (Figures 7(c) and 7(d)) has mean expected total costs of $429 \mathrm{mf}$, with a confidence interval that ranges between 70 and $1514 \mathrm{mf}$. Strategy 2f (Figure 8(a)) has mean expected total costs of $132 \mathrm{mf}$, with a confidence interval that ranges between 87 and $1026 \mathrm{mf}$, while the dynamic strategy (Figure 8(b)) has the lowest mean expected total costs $(70 \mathrm{mf})$.

In addition to the costs, it is also possible to see why they are likely to be incurred and who will incur them. Examples are shown in Figure 9, which show the supply, demand, water level and the difference between supply and demand if strategy $0,1 \mathrm{c}$ and $2 \mathrm{f}$ are followed. The supply-and-demand graphs show the 

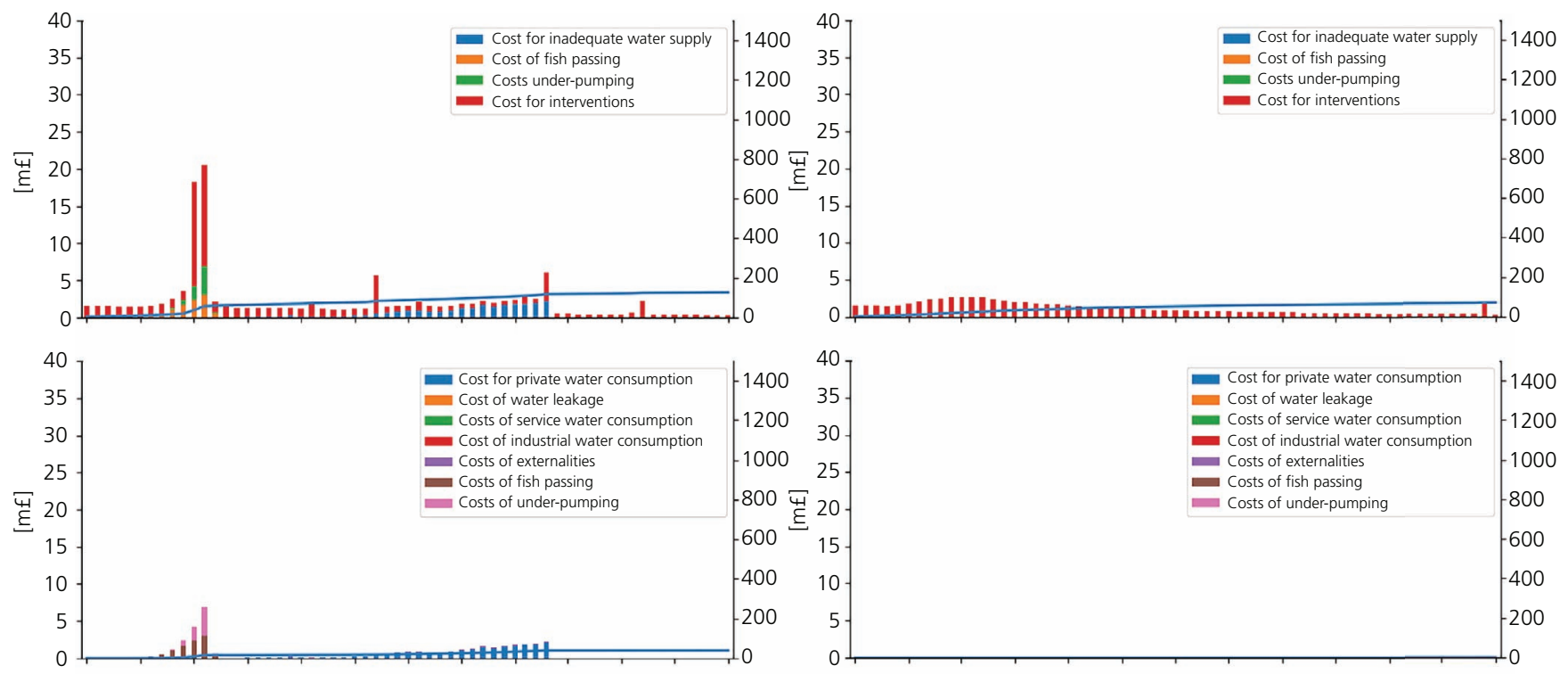

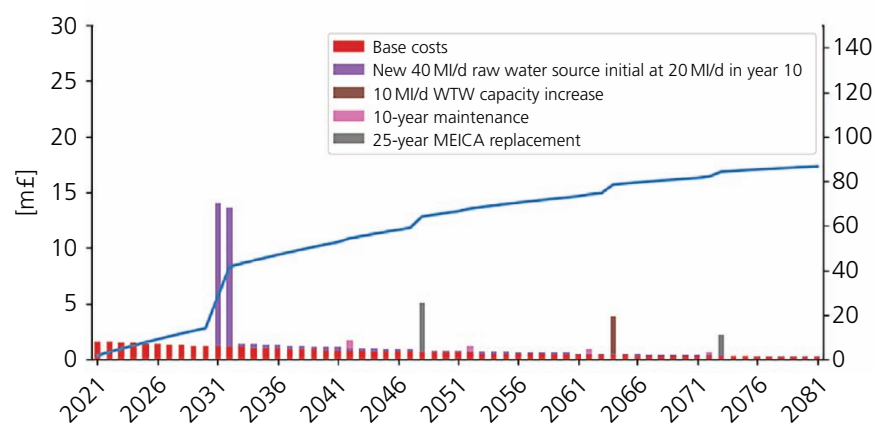

(a)

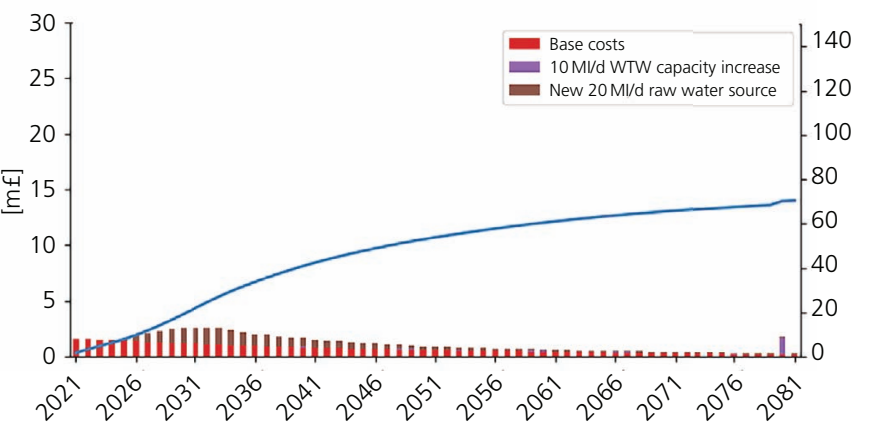

(b)

Figure 6. Costs associated with (a) strategy 2f: total costs, costs of inadequate service and intervention costs and (b) the dynamic strategy: total costs, cost for inadequate service and cost for interventions. MEICA, mechanical, electrical, instrumentation, control and automation assets; WTW, water treatment works

amount of water available and required, as well as the $95 \%$ confidence intervals and the capacity of the water treatment works. The water level graphs show the mean water level in the reservoirs, the $95 \%$ confidence intervals, the highest possible water levels, the limit for fish passage and the water level required to avoid incurring environmental costs. The water supply-demand graphs show the mean of the water supply to cover the demand for all uses, as well as the $95 \%$ confidence intervals.

It can be seen in Figure 9(b) that the water demand is foreseen to increase over time, mainly due to the expected growth in domestic use and that the supply for it (Figure 9(a)) will lead to under-pumping of the reservoirs from which the water is drawn starting from year 2031. In Figure 9(d), it can also be seen that the average amount of water required to satisfy the demand is well above both the distribution capacity and the demand.

Figure $9(\mathrm{c})$ shows that under strategy 0 , the water levels in the reservoirs are expected to be reduced below the critical level; that allows fish to pass by 2036 and below the level considered acceptable for environmental preservation. Figure 9(d) shows that the ratio between demand and supply is expected to turn negative (i.e. to cause a water shortage) by 2070 .

With strategy 1c (Figure 10): (i) the expected need of underpumping decreases significantly with respect to strategy 0 , and it is not expected to start before year 2036; (ii) the point in time where the critical water levels are passed is postponed to the time interval between 2050 and 2060, and (iii) the ratio between demand and supply never becomes negative. With strategy $2 \mathrm{f}$ (Figure 11): (i) there is only likely to be a small amount of underpumping before the construction of the new $10 \mathrm{Ml} / \mathrm{d}$ raw water source (i.e. year 10) and then none at all; (ii) the critical water level limits are never passed and (iii) the supply-demand ratio is always positive. A similar tendency can be seen with the dynamic strategy (Figure 12), as with strategy 2f. The differences, however, is that the interventions are only triggered when they yield the highest net benefit. The analysis associated with the dynamic strategy that there are only two types of interventions that may be triggered - that is, the construction of a new water 


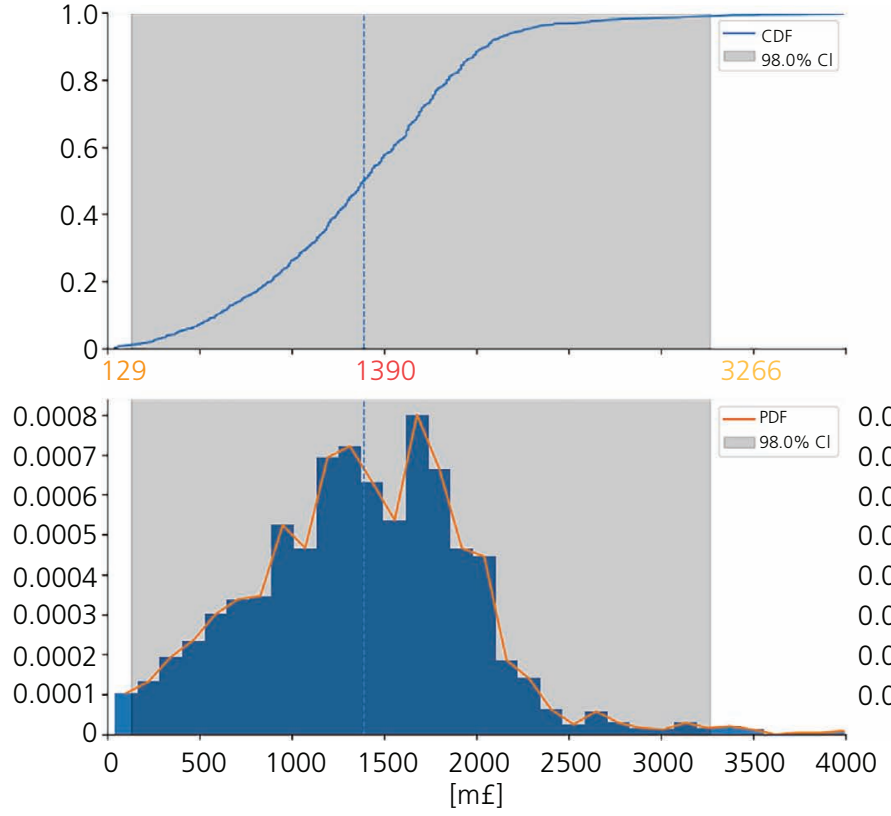

(a)

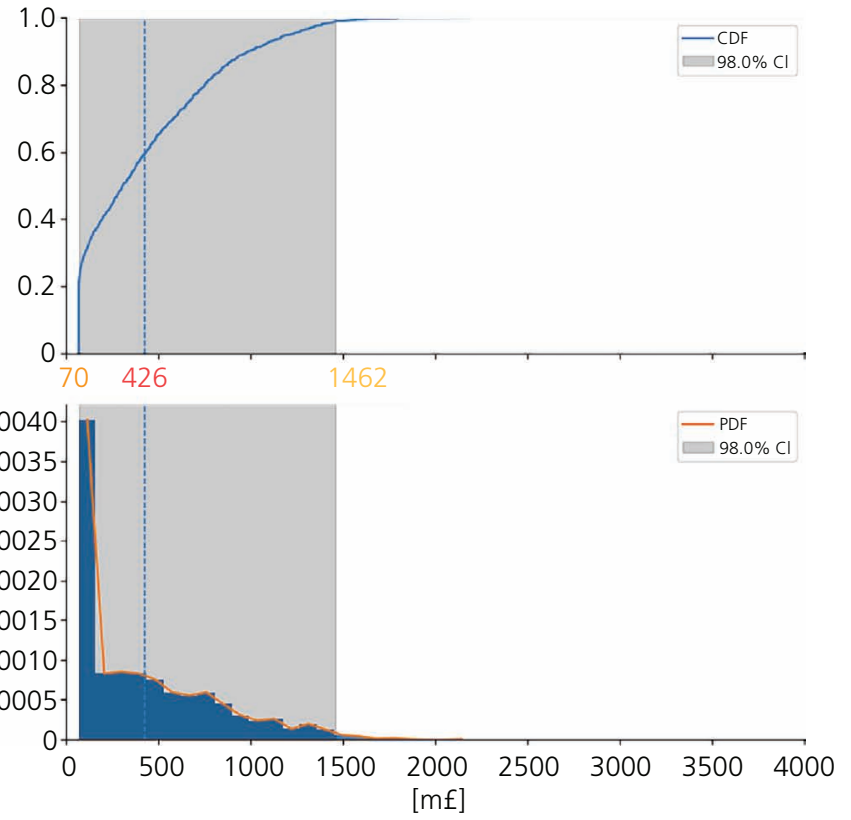

(b)

Figure 7. The (a) Cdf and Pdf for strategy 0 total costs and the (b) Cdf and Pdf for strategy $1 \mathrm{c}$ total costs. Cl, confidence interval

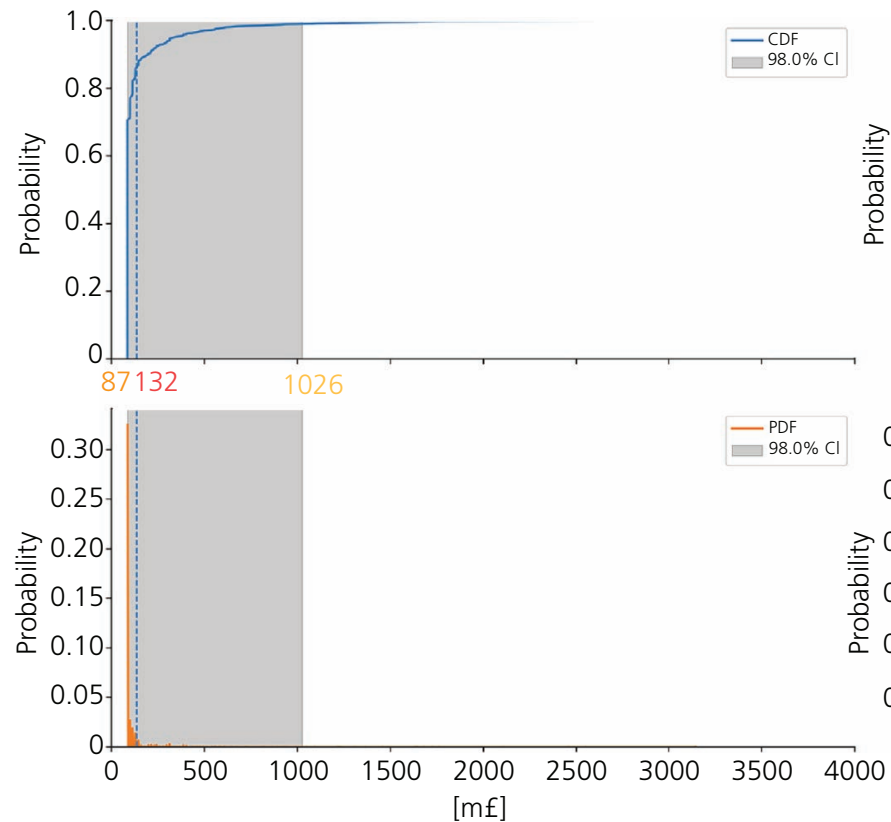

(a)

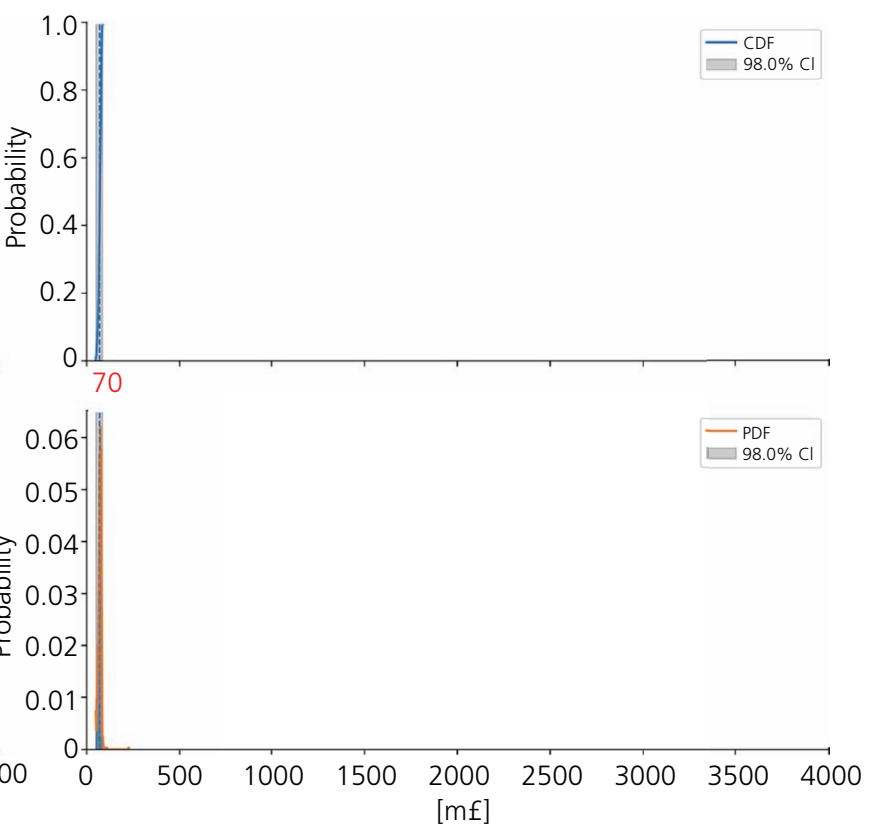

(b)

Figure 8. The (a) Cdf and Pdf for strategy $2 \mathrm{f}$ total costs and the (b) Cdf and Pdf for dynamic strategy total costs. Cl, confidence interval

source (intervention 3) and the increasing of the capacity of the existing water source by $20 \mathrm{Ml} /$ day (intervention $2 \mathrm{a}$ ). Intervention 3 might be triggered somewhere between 2041 and 2081 with a small probability. The probability is small because intervention 3 is only beneficial in the scenarios where there is a significant increase in demand, which has a small probability. Intervention 2a might be triggered in almost all the years, with a higher likelihood of being triggered earlier than later. This is because the net benefit of the investment is positive when there is only a small increase in demand. 


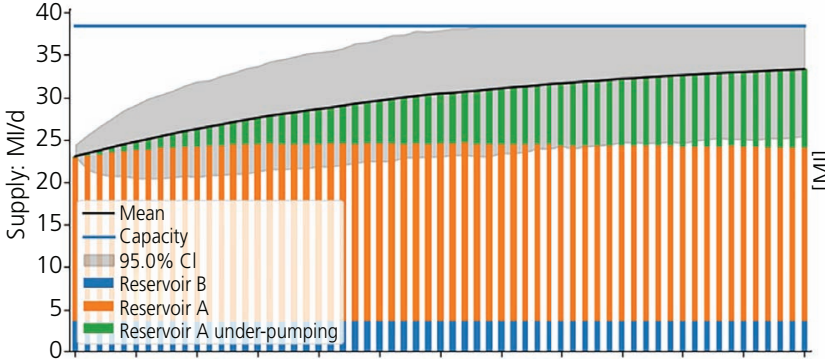

(a)

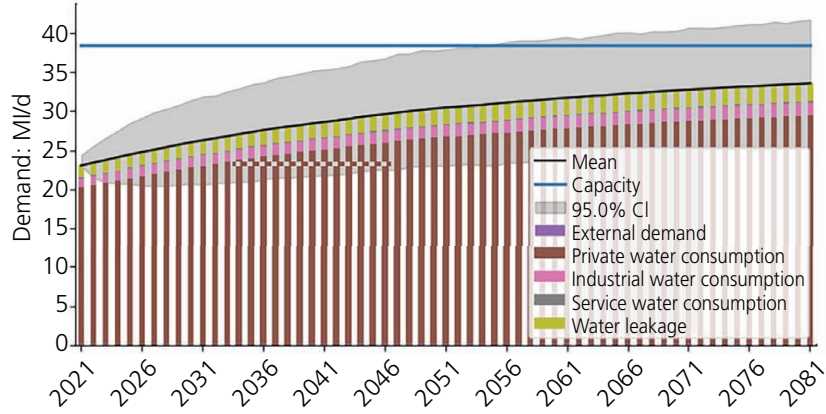

(b)

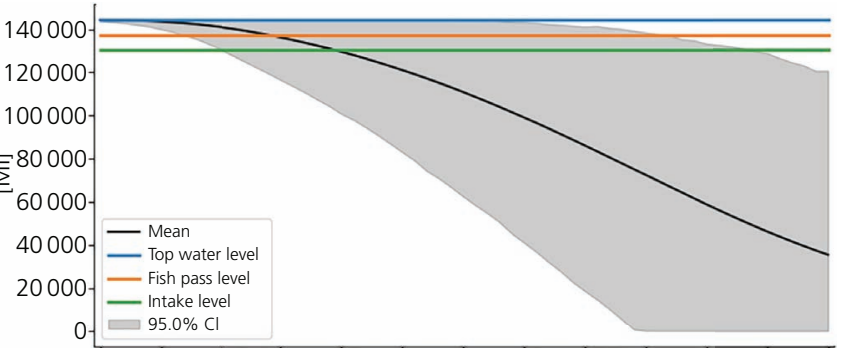

(c)

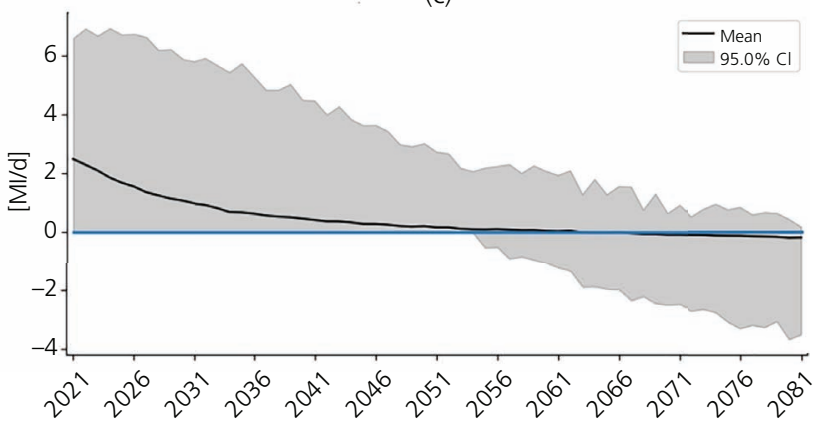

(d)

Figure 9. (a) Supply and (b) demand and (c) water level and (d) the difference between supply and demand if strategy 0 is followed

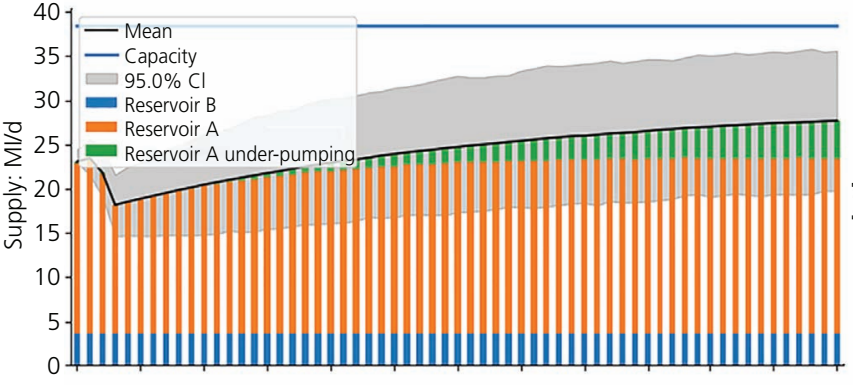

(a)

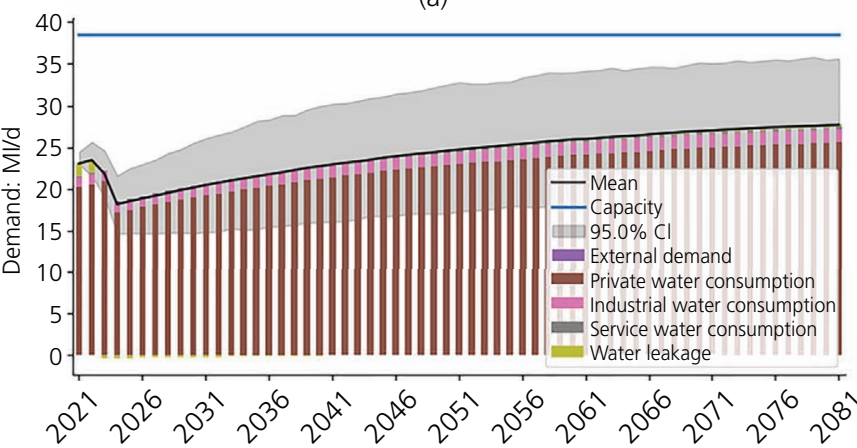

(b)

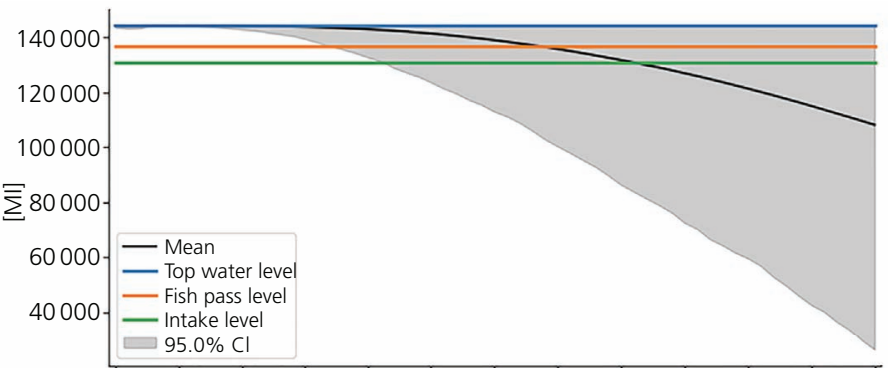

(c)

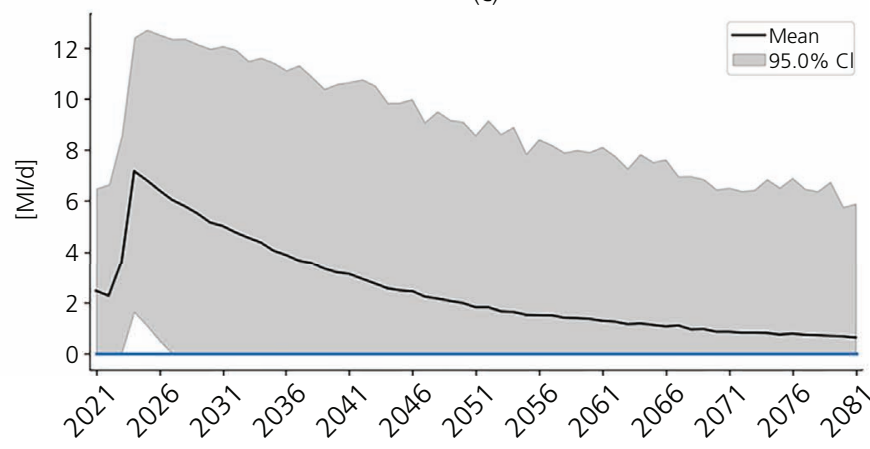

(d)

Figure 10. Supply (a) and demand (b) and water level (c) and the difference between supply and demand (c) if strategy $1 \mathrm{c}$ is followed

\section{Conclusion}

This paper demonstrates how to make investment decisions that optimally improve water supply resilience, taking into consideration both future uncertainty and management flexibility. It does so by appraising investment options using quantifiable benefits over time, including risk for multiple stakeholders. It is 
Investing in water supply resilience

considering uncertainty and management

flexibility

Adey, Martani and Hackl

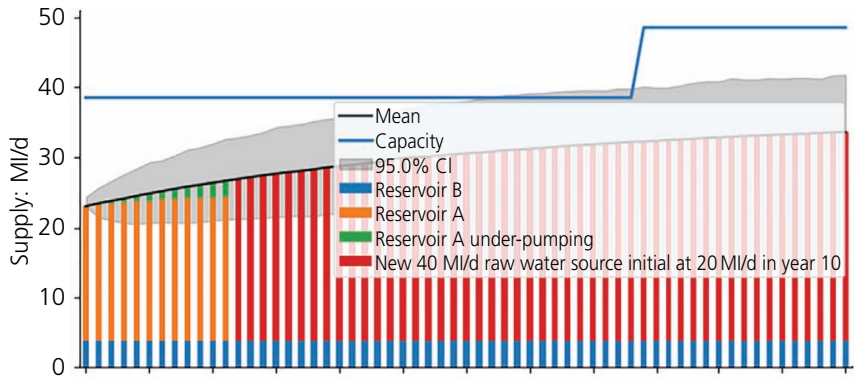

(a)

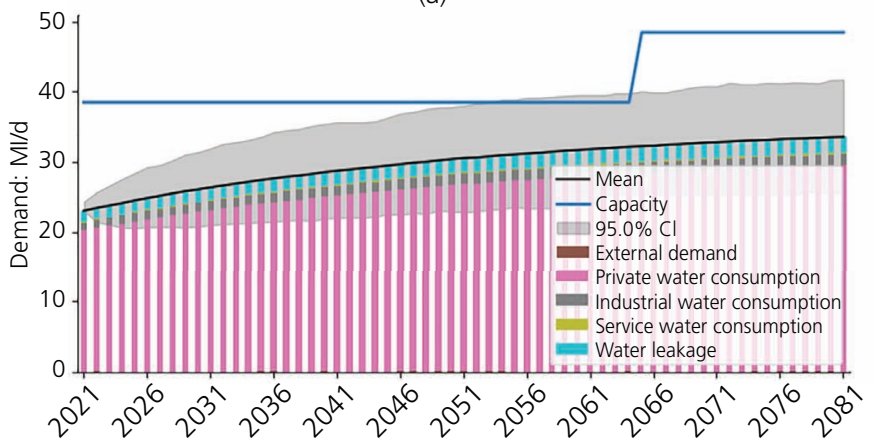

(b)

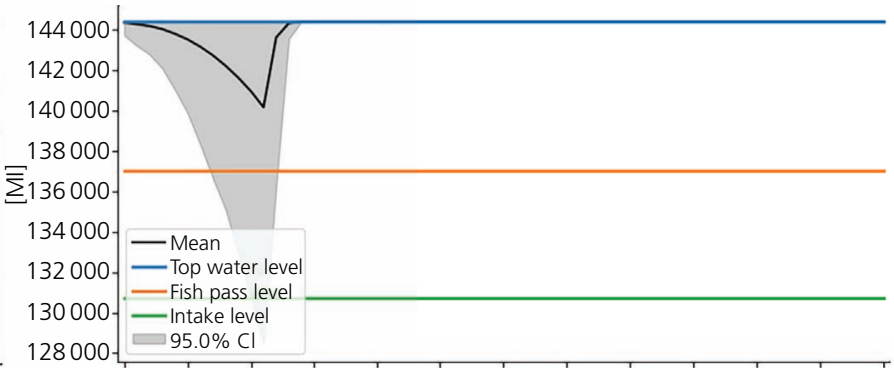

(c)

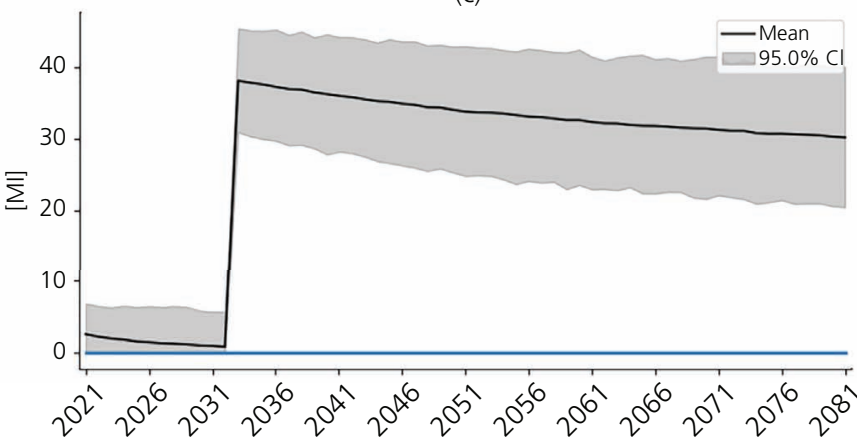

(d)

Figure 11. (a) Supply and (b) demand and (c) water level and (d) the difference between supply and demand if strategy $2 f$ is followed

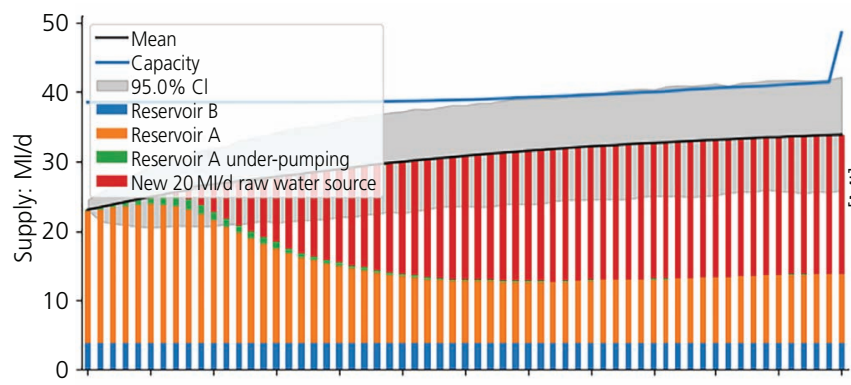

(a)

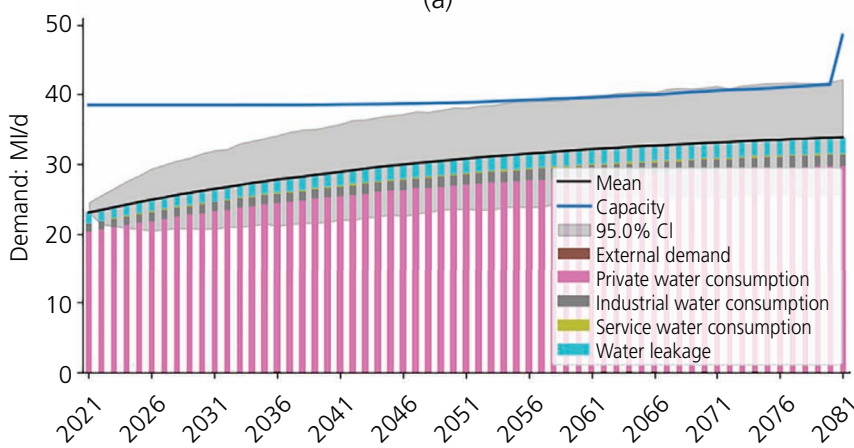

(b)

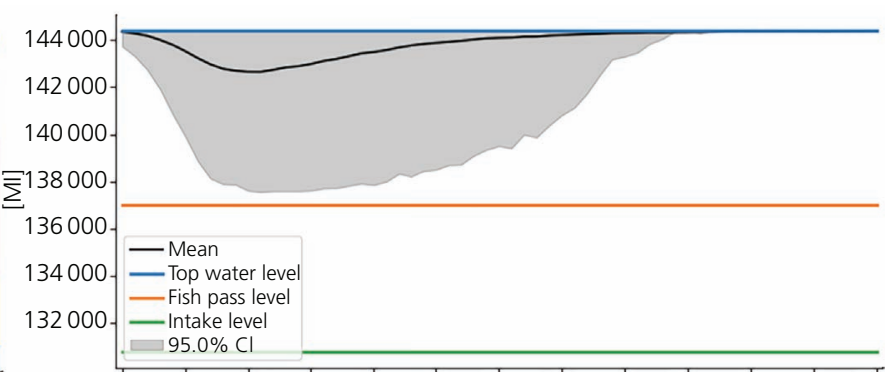

(c)

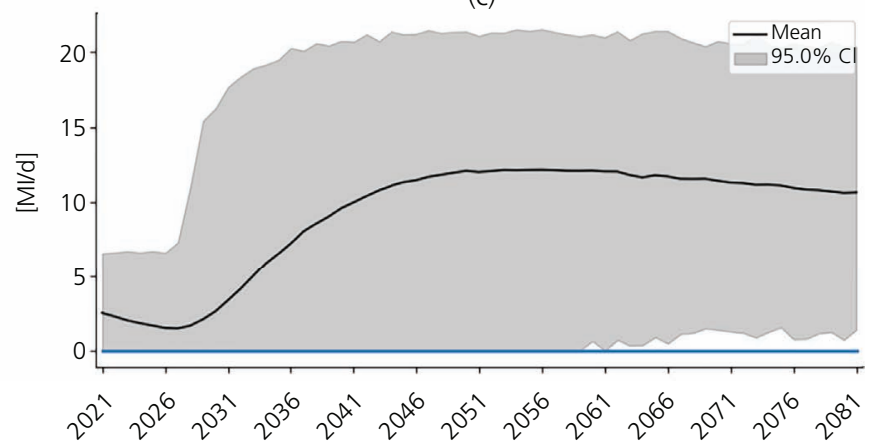

(d)

Figure 12. (a) Supply and (b) demand and (c) water level and (d) the difference between supply and demand if the dynamic strategy is followed

shown that this can be done with and without considering explicitly the ability of the manager to make decisions in the future based on new information. Considering management flexibility, however, provides more clarity as to whether an investment should be made or not, and if so, which intervention should be made and why. 
Smart Infrastructure and Construction

Volume 175 Issue 3
Investing in water supply resilience

considering uncertainty and management

flexibility

Adey, Martani and Hackl
For the example, it is shown that

- If static strategies are used in the appraisal of project investment options, no investment is currently required. This is because strategy $2 \mathrm{f}$, that is, raising the water availability by $40 \mathrm{ML} / \mathrm{d}$ at year 10 , and then of $10 \mathrm{ML} / \mathrm{d}$ each time at years 15 and 30 , is the optimal one, providing both the lowest expected total cost (i.e. $132 \mathrm{mf}$ ) and the highest expected net benefit (i.e. $1234 \mathrm{mf}$ ). This is principally due to the reduction in the costs of inadequate service, since when the water availability is expanded to $60 \mathrm{Ml} / \mathrm{d}$ over time, any chance that the water supply cannot satisfy the demand of one or more of the services, is small. Additionally, when this is done in three steps, the cost of interventions is pushed into the future, and is, therefore reduced through discounting. There is, however, a non-negligible probability that another intervention strategy would be chosen, for example, $2 \mathrm{~b}$, which is very close in total net benefit to $2 \mathrm{f}$, which would mean that a large investment would be required now.

- If a dynamic strategy is used in the appraisal, it is clear that no investment is currently required. It is likely that intervention $2 \mathrm{a}$, that is, raising the water availability by $20 \mathrm{Ml} / \mathrm{d}$, will happen relatively early over the investigated time period and intervention 3 , that is, raising the water availability by $35 \mathrm{Ml} / \mathrm{d}$, relatively late, but these decisions will need to be made at some point of time in the future which better reflects reality.

\section{Acknowledgements}

The authors would like to thank Scottish Water for their partial financing of this work and the technical support provided by Alan Scott in the creation of the example.

\section{REFERENCES}

Adey B, Martani C and Papathanasiou NMB (2019a) Estimating and communicating the risk of neglecting maintenance. Infrastructure Asset Management 6(2): 109-128, https://doi.org/10.1680/jinam.18.00027. Adey BT, Burkhalter M and Martani C (2019b) Defining road service to facilitate road infrastructure asset management. Infrastructure Asset Management 7(4): 240-255, https://doi.org/10.1680/jinam.18.00045.

Adey BT, Martani C, Kielhauser C et al. (2020) Guideline to measure service provided by, and resilience of, transport infrastructure. In $8 \mathrm{th}$ Transport Research Arena: Rethinking Transport. Towards Clean and Inclusive Mobility (TRA 2020). EU Transport Research Arena (TRA), Helsinki, Finland.

Ashuri B, Kashani H and Lu J (2011) An investment analysis framework for energy retrofit in existing buildings. In 47th ASC Annual International Conference. Associated Schools of Construction (ASC), Cheyenne, USA.

Cardin M-A and Hu J (2016) Analyzing the tradeoffs between economies of scale, time-value of money, and flexibility in design under uncertainty: study of centralized versus decentralized waste-to-energy systems. Journal of Mechanical Design. American Society of Mechanical Engineers 138(1): 11401.

Cardin M-A, Ranjbar-Bourani M and Neufville R (2015) Improving the lifecycle performance of engineering projects with flexible strategies: example of on-shore LNG production design. Systems Engineering 18(3): 253-268.

de Neufville R, Lee YS and Scholtes S (2008) Using flexibility to improve value-for-money in hospital infrastructure investments. In Infrastructure Systems and Services: Building Networks for a Brighter
Future (INFRA), 2008 First International Conference on. IEEE, Rotterdam, the Netherlands, pp. 1-6.

de Neufville R, Smet M, Cardin MA and Ranjbar-Bourani M (2019) Engineering Options Analysis (EOA): applications. In Decision Making under Deep Uncertainty. Springer, Cham, Switzerland, pp. 223-252.

De Neufville R and Scholtes S (2011) Flexibility in Engineering Design. MIT Press, Cambridge, USA.

De Neufville R, Scholtes S and Wang T (2006) Real options by spreadsheet: parking garage case example. Journal of Infrastructure Systems 12(2): 107-111.

Ellingham I and Fawcett W (2007) New Generation Whole-Life Costing: Property and Construction Decision-Making under Uncertainty. Routledge, London, UK.

Elvarsson AB, Martani C and Adey BT (2021) Considering automated vehicle deployment uncertainty in the design of optimal parking garages using real options. Journal of Building Engineering 34(1): 101703, https://doi.org/10.1016/j.jobe.2020.101703.

Esders M, Adey BT and Lethanh N (2016) Using real option methods as a tool to determine optimal building work programs. Structure and Infrastructure Engineering 12(11): 1395-1410.

Esders M, Martani C and Adey BT (2020) Evaluating initial building designs considering possible future changes and decision flexibility: the example of the new PET Centre of the University Hospital of Zurich. International Journal of Architecture, Engineering and Construction 9(4): 12020021.

Fawcett W and Chadwick A (2007) Space-time management and office floorspace demand: applied experience and mathematical simulations. Journal of Corporate Real Estate 9(1): 5-24.

Fawcett W and Rigby D (2009) The interaction of activity, space and cost variables in office workstation sharing. Journal of Corporate Real Estate 11(1): 38-51.

Fawcett W, Urquijo IR, Krieg H and Hughes M (2014) Cost and environmental evaluation of flexible strategies for a highway construction project under traffic growth uncertainty. Journal of Infrastructure Systems 21(3): 5014006.

Guma A and de Neufville R (2008) Real Option Analysis of a Vertically Expandable Real Estate Development. MIT, Cambridge, USA.

Martani C, Cattarinussi L and Adey BT (2018) A new process for the evaluation of the net-benefit of flexible ground-floor ceiling in the face of use transition uncertainty. Journal of Building Engineering 2018(15): $156-170$.

Papathanasiou N, Adey BT and Burkhalter M (2019) Defining and quantifying railway service to plan infrastructure interventions. Infrastructure Asset Management 7(3): 146-166, https://doi.org/10. 1680/jinam.18.00044

Santa-Cruz S and Heredia-Zavoni E (2011) Maintenance and decommissioning real options models for life-cycle cost-benefit analysis of offshore platforms. Structure and Infrastructure Engineering 7(10): 733-745.

\section{How can you contribute?}

To discuss this paper, please email up to 500 words to the editor at journals@ice.org.uk. Your contribution will be forwarded to the author(s) for a reply and, if considered appropriate by the editorial board, it will be published as discussion in a future issue of the journal.

Proceedings journals rely entirely on contributions from the civil engineering profession (and allied disciplines). Information about how to submit your paper online is available at www.icevirtuallibrary.com/page/authors, where you will also find detailed author guidelines. 